\section{Perceptual masking: Peripheral vs central factors*}

\author{
MITCHELL L. KIETZMAN $\dagger$, ROBERT C. BOYLE††, and DONALD B. LINDSLEY \\ Departments of Psychology and Physiology, \\ University of California, Los Angeles, California 90024
}

Perceptual masking was studied under binocular and dichoptic conditions in order to separate peripheral and central interference effects. Under binocular conditions, when the test flash (TF) and the blanking flash (BF) fell on both retinas, both retroactive and proactive masking were demonstrated. Under dichoptic conditions, when the TF fell on one eye and the $\mathrm{BF}$ on the other eye, thus eliminating opportunity for intraretinal interference, there was partial retroactive perceptual masking and no proactive masking. These results suggest that binocular proactive masking is due to peripheral light adaptation, that binocular retroactive masking is due to both peripheral and central effects, and that dichoptic masking is due solely to central retrochiasmal interference. It is proposed that dichoptic retroactive perceptual masking affords a method of investigating central perception time, i.e., the time to consolidate a perceptual experience.

It has long been known that perception of material presented in one flash can be interfered with by a closely following or preceding flash (Baxt, 1871; Cattell, 1885; Exner, 1868). Recently there has been a renewal of interest in related visual interference effects, such as perceptual masking, metacontrast, and rapid light-adaption phenomena (see reviews by Alpern, 1952; Blanc-Garin, 1967; Kahneman, 1968; Raab, 1963).

When a brief test flash (TF) containing information readily perceivable is followed after a short temporal interval by a brighter blanking flash $(\mathrm{BF})$, the information content of the first flash is masked or blanked out (Donchin, 1967; Donchin \& Lindsley, 1965; Donchin, Wicke, \& Lindsley, 1963; Lindsley, 1961; Lindsley \& Emmons, 1958). This is called retroactive or backward masking, since the second stimulus interferes with perception of the first stimulus. Perceptual masking also occurs when the BF precedes the TF; this is called proactive or forward masking.

There have been a number of studies of perceptual masking under binocular and monocular conditions of stimulation and a few under dichoptic (Battersby \& Wagman, 1962; Battersby, Oesterreich, \& Sturr, 1964; Boynton, 1961; Kolers \& Rosner, 1960; Schiller, 1965; Schiller \& Wiener, 1963; Wagman \& Battersby, 1959; Werner, 1940 ) conditions (TF to one eye and BF to the other). The present study has investigated both backward and forward masking under binocular and dichoptic conditions. In binocular stimulation, where

*This research was supported by NASA Grant NGL 05-007-049, U.S. Navy Contract N00014-69-A.0200-4024 and USPHS Grant NB-8552.

$\nmid$ Present address: Biometrics Research, 722 West 168th St., New York, N.Y. 10032.

++ Present address: Boeing Aircraft Co., Seattle, Washington. Ss under binocular and dichoptic conditions should help to determine the stimulations and judgments. nature and locus of the interference giving rise to perceptual masking.

The TF was a simple stimulus pattern provided by rear projection of a slide containing an annulus within which was a V-shaped sector. This circle-sector pattern appeared in a square opening on an opal glass screen in front of the $S$. The slide could be rotated so that the V-shaped sector appeared in any of four orientations, and the task of the $\mathrm{S}$ was to report whether it pointed up, down, right, or left. The light source for the TF was a Sylvania R1131C glow modulator tube producing a square-wave pulse. The brightness of the TF at 5-msec duration was sufficient for the $S$ to report the orientation of the sector correctly $100 \%$ of the time when the TF was presented alone. To insure easy discriminability of the pattern in this experiment, the duration of the TF was increased to $10 \mathrm{msec}$. The circle-sector pattern appeared on the screen as a white image against a dark background; the outer edge of the annulus was contiguous with the margins of the square viewing area. The diameter of the annulus subtended a visual angle of $2 \mathrm{deg}$ and was thus mainly confined to the foveal area. The $\mathrm{BF}$ stimulus was provided by a Grass PS-1 photostimulator at intensity setting 4 ; the 20-microsec BF uniformly illuminated the square viewing area upon which the TF

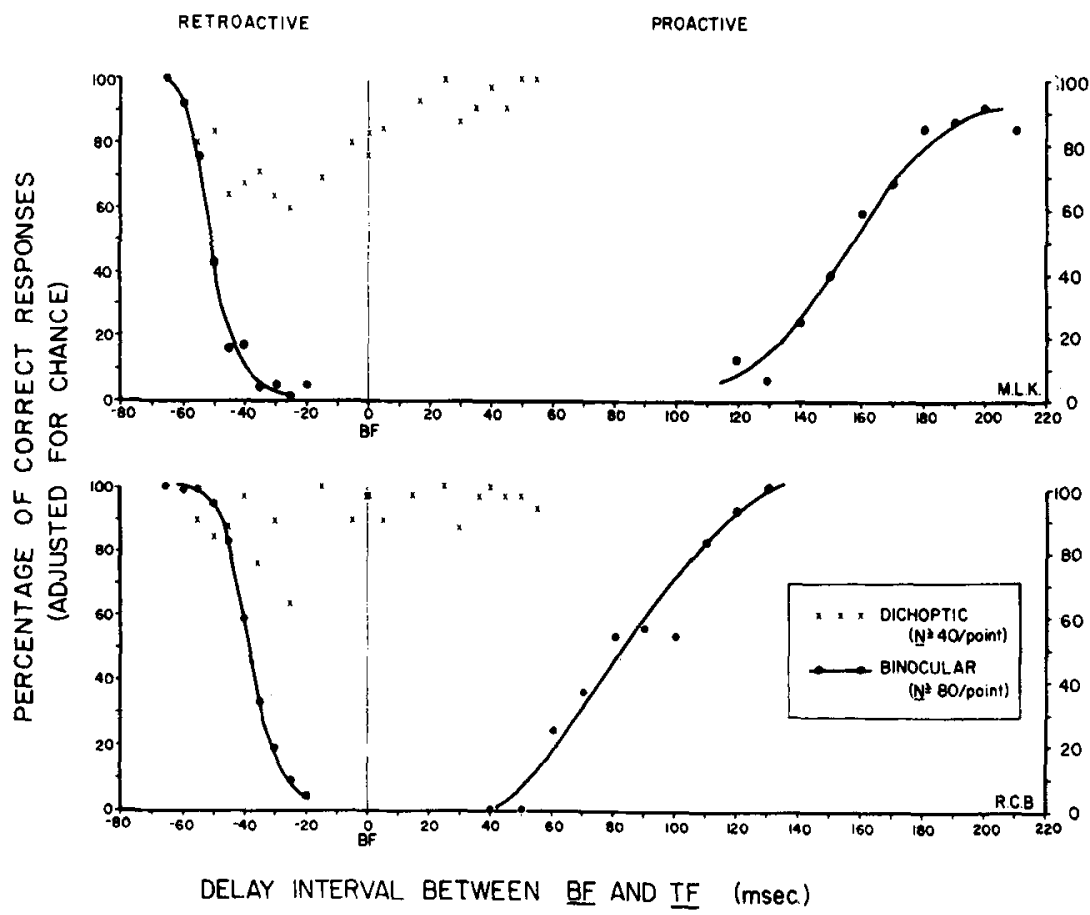

Fig. 1. Graphs of retroactive and proactive masking effects for two Ss (M.L.K. and R.C.B.) under binocular and dichoptic conditions. In the retroactive condition the test flash (TF) preceded the blanking flash (BF); in the proactive condition the TF followed the BF. Each plotted point is based on at least 40 (dichoptic) or 80 (binocular) $\mathrm{S}$ 
appeared either before or after the BF. The brightness ratio of $\mathrm{BF}$ to $\mathrm{TF}$ was approximately 100 to 1 .

The time, or delay interval, between the $\mathrm{TF}$ and $\mathrm{BF}$ was the independent variable. The percentage of presentations at each delay interval for which the $S$ could identify correctly the orientation of the $V$-shaped sector was the dependent variable. Ss were dark adapted for $20 \mathrm{~min}$ prior to the presentation of stimuli; they fixated a red spot in the center of the viewing area and when ready stimulated themselves by pressing a switch. The $\mathrm{E}$, in another room, adjested the position of the sector in the TF according to a random order and regulated the TF-BF delay intervals. Each block of 20 stimulus presentations had the same TF-BF delay interval and these interflash intervals were varied randomly for the various blocks of trials within a session.

Nine Ss with normal vision were studied preliminarily. Only four of these showed consistently an appreciable amount of retroactive masking under dichoptic conditions of stimulus presentation; none showed dichoptic proactive masking. Two of the four exhibiting dichoptic retroactive masking, who were experienced in making visual perceptual judgments, were then subjected to intensive study of retroactive and proactive masking under binocular and dichoptic conditions. The data from these two Ss were obtained in a series of sessions extending over several experimental days.

Figure 1 presents separate graphs of results for each $\mathrm{S}$. The blanking flash (BF) is located at time zero on the abscissa. Retroactive masking is shown to the left with negative delay intervals representing the time between the onset of TF and BF; proactive or forward masking is shown to the right.

In the binocular retroactive masking condition, where TF preceded BF, both Ss showed characteristic masking as a function of the duration of the delay interval. There was complete masking at delay intervals up to 20 or $25 \mathrm{msec}$ and no masking beyond $60 \mathrm{msec}$. With delay intervals from about 25 to $60 \mathrm{msec}$, masking was partial, occurring on only a certain percentage of trials; as the delay interval was lengthened, discriminability of the V-sector improved rapidly.

In the binocular proactive masking condition ( $\mathrm{BF}$ followed by $\mathrm{TF}$ ), the duration of the masking varied for the two Ss but in each instance was longer than in the retroactive condition. Comparable differences between retroactive and proactive masking have been reported by others (Schiller \& Smith, 1965; Smith \& Schiller, 1966). For MLK, complete masking extended to $120 \mathrm{msec}$, with no masking beyond $210 \mathrm{msec}$; for RCB, complete masking extended to $50 \mathrm{msec}$, and there was no masking beyond $130 \mathrm{msec}$. The duration of proactive masking was approximately three times longer than for retroactive masking. This difference is probably due to the fact that a bright stimulus precedes a dim stimulus in the proactive masking condition, thus producing light adaptation and photochemical effects. These effects would be minimal in the retroactive masking condition in which the dim light (TF) precedes the brighter light $(\mathrm{BF})$.

Of special interest are the marked differences between the binocular and dichoptic results. Whereas binocular retroactive masking for both $\mathrm{Ss}$ was complete from 0 to $20 \mathrm{msec}$ and partial from 20 to $60 \mathrm{msec}$, dichoptic masking was only partial through these ranges of delay intervals and never fell below the $60 \%$ level of correct responses. Although both Ss showed prominent proactive masking binocularly, neither $S$ showed an appreciable amount of proactive masking dichoptically. Results from other masking studies suggest that the absence or presence of proactive masking depends upon certain stimulus parameters (Battersby \& Wagman, 1962; Battersby, Oesterreich, \& Sturr, 1964). For example, Battersby et al (1964) state, "The change in threshold sensitivity in one eye, due to the introduction of an annulus target in the other, depends upon the luminosity, spatial and temporal dimensions of the two targets [p. 1185]."

In the case of the dichoptic retroactive masking, interference can only be retrochiasmal, i.e., centralward of the optic chiasm, either in the lateral geniculate nucleus or in the visual cortex. The optic fibers from the two eyes project to alternate laminae of the lateral geniculate nucleus, and interactions there are thought to be minimal (Sturr \& Battersby, 1966); thus the interference giving rise to dichoptic retroactive masking probably occurs in the visual cortex.

Recent evidence indicates that binocular or monocular retroactive masking effects with very short interflash intervals may be accounted for mainly in terms of interactions occurring peripherally in the retina (Fehmi, Adkins, \& Lindsley, 1969; Robinson, 1968; Sturr \& Battersby, 1966). However, the dichoptic masking observed in this study, though only partial, suggests that binocular retroactive masking may also have a central component. Since, dichoptically, there is no proactive masking and hence no central interference, binocular proactive masking must be attributed to peripheral effects within the retina.

It appears that dichoptic retroactive masking procedures, especially if made more refined by appropriate choice of stimuli, could be used to study the timing of central processes underlying the consolidation of perception, a measure which might be labelled central perception time, as first suggested by Lindsley and Emmons (1958).

\section{REFERENCES}

ALPERN, M. Metacontrast. Historical introduction. American Journal of Optometry, 1952, 29, 631-646.

BATTERSBY, W. S., OESTERREICH, R. E., \& STURR, J. F. Neural limitations of visual excitability. VII. Nonhomonymous retrochiasmal interaction. American Journal of Physiology, 1964, 206, 1181-1188.

BATTERSBY, W. S., \& WAGMAN, I. H. Neural limitations of visual excitability. IV. Spatial determinants of retrochiasmal interactions. American Journal of Physiology, 1962, 203, 359-365.

BAXT, N. Über die Zeit welche nötig ist, damit ein Gesichtseindruck zum Bewusstsein kommt und uber die Grüsse (Extension) der bewussten Wahrnehmung bei einem Gesichtseindrucke von gegebener Dauer. Pflüger's Archiv für die gesamte Physiologie, 1871, 4, 325-336.

BLANC-GARIN, J. Le masquage visuél rétroactif. Année Psychologie, 1967, 67, 153-193.

BOYNTON, R. M. Some temporal factors in vision. In W. A. Rosenblith (Ed.), Sensory communication. New York: Wiley, 1961. Pp. 739-756.

CATTELL, J. M. The inertia of the eye and brain. Brain, 1885, 8, 295-312.

DONCHIN, E. Retroactive visual masking: Effect of test flash duration on the masking interval. Vision Research, 1967, 7, 79-87.

DONCHIN, E., \& LINDSLEY, D. B. Visually evoked response correlates of perceptual masking and enh ancement. Electroencephalography \& Clinical Neurophysiology, 1965, 19, 325-335.

DONCHIN, E., WICKE, J. D., \& LINDSLEY, D. B. Cortical evoked potentials and perception of paired flashes. Science, 1963, 141, $1285-1286$

EXNER, S. Ueber die zu einer Gesichtswahrehmung nothige Zeit. Sitzungsbericht Wien Akademie Wissenschaften, $1868,58,601-632$.

FEHMI, L. G., ADKINS, J. W., \& LINDSLEY, D. B. Electrophysiological correlates of visual perceptual masking in monkeys. Experimental Brain Research, 1969, 7, 299-316.

KAHNEMAN, D. Method, findings, and theory in studies of visual masking. Psychological Bulletin, 1968, 70, 404-425.

KOLERS, P. A., \& ROSNER, B. S. On visual masking (metacontrast): Dichoptic observation. American Journal of Psychology, $1960,73,2-21$

LINDSLEY, D. B. Electrophysiology of the visual system and its relation to perceptual phenomena. In M. A. B. Brazier (Ed.), Brain and behavior. Vol.I. Washington, D.C: American Institute of Biological Sciences, 1961. Pp. 359-392.

LINDSLEY, D. B., \& EMMONS, W. H. Perception time and evoked potentials. Science, 1958, 127, 1061. (Abstract)

RAAB, D. H. Backward masking. Psychological Bulletin, 1963, 60, 118-129.

ROBINSON, D. N. Visual disinhibition with binocular and interocular presentations. 
Journal of the Optical Society of America, $1968,58,254-257$.

SCHILLER, P. H. Monoptic and dichoptic visual masking by patterns and flashes. Journal of Experimental Psychology, 1965, 69, 193-199. SCHILLER, P. H., \& SMITH, M. C. A comparison of forward and backward masking. Psychonomic Science, 1965, 3, 77-78.

SCHILLER, P. H., \& WIENER, M. Monoptic and dichoptic visual masking. Journal of Experimental Psychology, 1963, 66, 386-393. SMITH, M. C., \& SCHILLER, P. H. Forward and backward masking: A comparison. Canadian Journal of Psychology, 1966, 20, 191-197,

STURR, J. R., \& BATTERSBY, W. S. Neural limitations of visual excitability. VII: Binocular convergence in cat geniculate and cortex. Vision Research, 1966, 6, 401419.
WAGMAN, I. H., \& BATTERSBY, W. S. Neural limitations of visual excitability. Il: Retrochiasmal interaction. American Journal of Physiology, 1959, 197, 1237-1242.

WERNER, H, Studies on contour. Strobostereoscopic phenomena. American Journal of Psychology, 1940, 53, 418-422.

(Accepted for publication August 4, 1970.) 